\title{
Piotr LASKowski
}

INSTYTUT SOCJOLOGII

UNIWERSYTET W BIAEYMSTOKU

EMAIL: P.LASKOWSKI@UWB.EDU.PL

\section{„SZKOŁA W INTERNECIE”: WOJEWÓDZTWO PODLASKIE \\ I MAZOWIECKIE - REGIONALNE ZRÓŻNICOWANIA W WYKORZYSTANIU INTERNETU W EDUKACJI NA POZIOMIE PODSTAWOWYM, GIMNAZJALNYM I PONADGIMNAZJALNYM}

\section{Internet w szkole - szkoła w Internecie}

Wykorzystanie Internetu - sieci tworzącej dynamiczną przestrzeń, w której rozwijają się wszelkiego rodzaju kursy, powstają strony encyklopedyczne, portale tematyczne wypełnione fachową wiedzą, fora dyskusyjne osób podzielających wspólne zainteresowania, e-wydawnictwa udostępniające opracowania naukowe - w edukacji na wszystkich jej szczeblach staje się w XXI wieku standardem [Nowak, Winkowska-Nowak 2009]. Informacja edukacyjna jest dostępna niezależnie od miejsca i czasu. Dostęp do zasobów informacyjnych sieci uległ delokalizacji przestrzennej i temporalnej. W dowolnym momencie i w dowolnym miejscu, dysponując mobilnym środkiem komunikacji, można zacząć naukę i w dowolnym momencie można ją przerwać i do niej wrócić. Można dopasowywać sposób przyswajania wiedzy do naszych osobistych możliwości i preferencji. Sami zaczynamy decydować o tym, jaki sposób tempo i zakres przekazu wiedzy i informacji jest dla nas najlepszy, najciekawszy, czy też najbardziej efektywny. Medium przekazującym może być film, dokument, czy też forma interaktywnej zabawy (szczególnie atrakcyjna forma edukacji dla najmłodszych), gdzie w zależności od naszych wyborów dostaniemy różne informacje zwrotne. Wszystko to już istnieje równolegle $\mathrm{z}$ nami, młodzi ludzie (uczniowie szkół podstawowych, gimnazjalnych i ponadgimnazjalnych) nie znają już z własnego doświadczenia „życia z epoki przedkomupterowej”, świata bez Internetu. Internet w szkole nie jest już tylko jednym $z$ dodatkowych „narzędzi dydaktycznych", jest on częścią świata, w którym uczniowie żyją, 
których sposób odnoszenia się do świata i siebie nawzajem jest uwarunkowany przez doświadczenie „bycia w sieci”. Czy współczesna szkoła powszechna potrafi wykorzystywać efektywnie Internet w procesie edukacyjnym? Jeśli tak, to $\mathrm{w}$ jakim stopniu jest on wykorzystywany przez szkoły podstawowe, gimnazjalne i ponadgimnazjalne? W jaki sposób odbywa się komunikacja przez to medium? Jakie zachodzą interakcje między uczestnikami komunikacji, którymi są uczeń, nauczyciel i rodzic (opiekun)? Alternatywa dla schematycznych i tradycyjnych form edukacji, jaką stał się (lub staje się) Internet, oferuje dostęp do wiedzy w każdym miejscu, o każdej porze. Dostęp do źródeł informacji pozostaje jednak poza kontrolą nauczycieli i rodziców (opiekunów). Internet może się stać „alternatywnym źródłem autorytetu” - źródłem wiedzy, wzorców postępowania, wartości (zarówno pozytywnych, jak negatywnych). Postępująca cyfryzacja powoduje, że część naszego życia przenosi się do Internetu. Czy szkoły (podstawowe, gimnazja, szkoły ponadgimnazjalne) województwa podlaskiego funkcjonują efektywnie w tej nowej rzeczywistości technologicznej i kulturowej i są w niej wyraźnie widoczne, czy wiedza przez nie oferowana jest również tam dostępna, czy i w jakim zakresie i formach proces komunikowania się między uczniami, nauczycielami i rodzicami przez to medium jest wykorzystywany w procesie dydaktycznym w szkołach województwa podlaskiego? Czy szkoła może efektywnie przełamywać regionalne i społeczne uwarunkowania „wykluczenia cyfrowego” [Batorski 2009; Jeran 2008, 2009]. Jeśli jednak upowszechnienie technologii internetowych w edukacji jest zróżnicowane regionalnie, to rodzi się obawa, że Internet może stać się nowym źródłem tworzenia i podtrzymywania regionalnych nierówności rozwojowych, w których nierówności edukacyjne zaczynają odgrywać - w dobie społeczeństwa informacyjnego - rolę podstawową.

W erze Internetu młodzież korzysta biegle z komunikacji zapośredniczonej przez komputer i witryny internetowe szkół muszą zabiegać o uwagę i starać się o atrakcyjność treści (materiałów) zamieszczanych na stronach. A konkurencja o uwagę na „rynku medialnym” jest silna. Trudno dziś sobie wyobrazić życie jednostki i społeczeństwa bez nowoczesnych technologii komunikowania się. Stajemy się „niewolnikami” naszych technologii, bez nich nie możemy się obejść. Pamiętajmy też, że Internet, to nie tylko to, co pożyteczne i przyjemne, ma on również swoją „ciemną stronę" - może być wykorzystany w sposób nieakceptowalny społeczne, stwarzając zagrożenie nowymi formami przestępczości, agresji, patologii. Nie dziwi więc, że stał się przedmiotem badań socjologicznych [Bolter 1990; Krzysztofek, Szczepański 2002; Goban-Klas 2005; Bard, Soderqvist 2006; Castells 2007]. 
W tym artykule odnoszącym się do problematyki wykorzystania technologii internetowych w edukacji na poziomie podstawowym, gimnazjalnym i ponadgimnazjalnym, skoncentruję swą uwagę na analizie funkcjonalności witryn internetowych w perspektywie porównania regionalnego (województwo podlaskie - województwo mazowieckie). Uczniowie szkół regionu podlaskiego funkcjonują $\mathrm{w}$ dwóch układach odniesienia: układu regionalnego zróżnicowania (centrum-peryferie) związanego z nierównomiernością poziomu rozwoju infrastruktury (w tym również informatycznej) oraz układu pogranicza rzeczywistości realnej (Internet w szkole) i wirtualnej (szkoła w Internecie). Czy i jakie mogą mieć konsekwencje społeczne owe układy odniesienia? Problematykę wykorzystania Internetu w procesie dydaktycznym i wychowawczym przez nauczycieli i rodziców oraz konsekwencje społeczne (pozytywne i negatywne) podejmę w odrębnych publikacjach.

\section{Internetowe witryny szkolne}

Przedmiotem analizy są witryny internetowe („strony WWW”) szkół podstawowych, gimnazjalnych i ponadgimnazjalnych województwa podlaskiego z wykluczeniem Białegostoku oraz województwa mazowieckiego z wykluczeniem Warszawy. W analizie skupiono się na peryferiach, celowo pomijając jednostki centralne: Białystok i Warszawę. Wylosowano 80 szkół z każdego województwa oraz przeanalizowano je pod kątem:

- Funkcjonalności: istnienia adresu w Internecie, modularnej budowy, oferowanych funkcjonalności; spełniania (a) standardów stricte technicznych, jak np. poprawności wyświetlania, odpowiadających za czytelność treści strony (tekst, zdjęcia, grafika) niezależnie od użytego do przeczytania strony środowiska, przeglądarek www; oraz (b) standardów „nietechnicznych”, w których uwagę warto zwrócić na zasoby danych gromadzone i wyświetlane na stronach, na standardy i metody przekazywania informacji, na to, w jaki sposób szkoła może działać na odbiorcę mobilizując go, wpływając na niego, aby włączył się, lub brał czynny udział w życiu szkoły, bądź szerzej w życiu społeczności lokalnej. W jaki sposób witryna szkolna może pobudzać aktywność społeczną odbiorców. Jak szkoła zachęca swoich odbiorców do włączania się w projekty organizowane przez szkołę oraz do przystępowania do wszelkich inicjatyw o charakterze lokalnym. 
- Standardów redakcyjnych: spełniania obecnie obowiązujących zasad budowy treści oraz sposobu ich formatowania i wyświetlania, co - jak wiadomo - ma bezpośrednie przełożenie na wyszukiwarki, które indeksują naszą stronę według słów kluczowych oraz treści zawartych w dokumencie wraz ze znacznikami HTML. „Meta keywords” - czyli słowa kluczowe - wstawiane są do opisu strony i każda strona powinna mieć zdefiniowany przez użytkownika zestaw słów kluczowych, które będą adekwatne do treści zawartych na stronie. Znaczniki, czyli tagi HTML, budują strukturę strony. Opisują je dwie cechy: atrybuty i zawartość. Cechy te muszą spełniać określone wymagania, aby dokument był poprawnie wyświetlany, np. jako „nagłówek” lub jako „hiperłącze”, czyli odnośnik do innego miejsca na stronie lub do innej strony WWW. Zaśmiecony kod odbija się na pozycji strony, na jej widoczności w wyszukiwarkach i niejednokrotnie powoduje, że bot indeksujący ${ }^{1}$ naszą stronę pomija ją ze względu na dużą liczbę błędów w składni. Często również nasza strona nie może być przeczytana poprawnie przez przeglądarkę określonego typu (Google Chrome, Firefox, Internet Explorer, Opera i inne). Powodów może być kilka, przykładowe to: rozjeżdżający się tekst, za duży obrazek, długo wczytujące się obrazki - brak optymalizacji wyświetlania grafiki, strona wczytująca się częściowo ze względu na błędy występujące w składni HTML, bądź też przez to ze bezpośrednio z edytora tekstowego przerzucamy treść wprost na stronę. Grafika przygotowana do użycia na stronie powinna się różnić od tej, która zostałaby użyta do druku wysokiej jakości.

- Użycia nowych form i metod kreowania wizerunku witryny: należy tu wziąć pod uwagę obsługę urządzeń typu smartfon lub tablet, do których strona powinna być osobno przygotowana. Ma to związek mniejszą wyświetlaną rozdzielczością oraz z mniejszym ekranem, na którym strona ma pozostać tak samo czytelna jak na dużym ekranie. Zwracanie uwagi na poprawne napisanie tekstu aktualności w taki sposób, aby był on dobrze widoczny na stronie, aby zachęcał do pełnego rozwinięcia i przeczytania całego tekstu, aby posiadał wyróżniający się tytuł. Wyda-

Robot internetowy (lub też Robot indeksujący) - jest programem zbierającym informacje o strukturze i stronach umieszczanych w indeksie wyszukiwarek i służą m.in. do: dodawania do wyszukiwarek, sprawdzania kodu strony, zbierania informacji o stronie, monitorowania „co nowego”, tworzenia mirrorów stron. Źródło: http://pl.wikipedia.org/wiki/Robot_internetowy [10.12.2012]. 
je się, że strony powinny zacząć używać w budowie HTML5² oraz CSS333, co powoduje większą atrakcyjność strony, a także daje większe możliwości w budowaniu i umieszczaniu treści czy też ankiet, bądź formularzy. Skojarzenie witryny z serwisem społecznościowym, najpopularniejszym wydaje się Facebook, obok takich jak Grono, Nasza Klasa czy Tweeter. Umieszczanie treści audio i video na zewnętrznych serwisach to tego przygotowanych, np. YouTube.

\section{Widoczność witryny szkolnej w przestrzeni internetu}

Witryna szkolna jest wizytówką szkoły, jej prezentacją, projekcją, do której każda osoba korzystająca $\mathrm{z}$ Internetu ma dostęp. Powinna więc istnieć „w sieci”, ale samo istnienie nie jest warunkiem wystarczającym. Dodatkowo witryna powinna spełniać standardy obowiązujące w czasach obecnych. Powinna mieć „niezaśmiecony kod”, który wpływa na pozycję strony w Internecie i zawierać ciekawe treści, które mogą przyciągnąć ucznia, rodzica (opiekuna) bądź nauczyciela do częstych odwiedzin strony. Wydaje się, że powinna też pełnić rolę, która została szkole przeznaczona, czyli „nieść kaganek oświaty” i posiadać edukacyjne treści podane w atrakcyjnej formie oraz wykorzystywać narzędzia wspomagające dydaktykę przez Internet (gry i zabawy interaktywne, quizy, konkursy, sondy/ ankiety). Odnośniki do ciekawych stron zawierających przydatne materiały powinny stanowić integralną część witryn szkolnych. Witryny powinny oferować swoim podopiecznym możliwość kształcenia się, uzupełniania wiedzy poprzez platformy e-learningowe. Wychodzenie naprzeciw użytkownikom wydaje się bardzo ważne, interakcja, komunikacja może się też odbywać poprzez dodatkowe kanały informacyjne. Ważną rolę w przestrzeni szkoły zaczynają pełnić serwisy społecznościowe, z których młodzi ludzie korzystają naturalnie, komunikując się, wymieniając doświadczeniami i opiniami. W tym medium wydaje się, że

2 HTML5 - język wykorzystywany do tworzenia i prezentowania stron internetowych www. Jest rozwinięciem języka HTML 4 i jego XML-owej odmiany (XHTML 1), opracowywane w ramach prac grupy roboczej WHATWG (Web Hypertext Application Technology Working Group) i W3C. Źródło: http://pl.wikipedia.org/wiki/HTML_5 [10.12.2012] źródło: http://pl.wikipedia.org/wiki/HTML_5 [10.12.2012].

3 Kaskadowe arkusze stylów (ang. Cascading Style Sheets - CSS) to język służący do opisu formy prezentacji (wyświetlania) stron WWW. CSS został opracowany przez organizację W3C w 1996 roku jako potomek języka DSSSL przeznaczony do używania w połączeniu z SGML-em. Pierwszy szkic CSS zaproponował w 1994 roku Håkon Wium Lie. źródłó: http://pl.wikipedia.org/wiki/Kaskadowe_ arkusze_stylów [10.12.2012]. 
brak jest szkoły, nie widać jej aktywności, a na pewno znajdzie się tam dla niej miejsce. Spośród przeanalizowanych szkół województwa podlaskiego (bez Białegostoku) i mazowieckiego (bez Warszawy) w Internecie istnieje 78,8\% z wszystkich przeanalizowanych szkół. Występuje jednak istotna (statystycznie) różnica między regionami; $28,7 \%$ szkół z województwa podlaskiego nie posiada strony, bądź strona została zawieszona i nie istnieje pod podanym adresem. Wynik jest dużo gorszy niż dla województwa mazowieckiego, w którym 13,8\% szkół nie istnieje $\mathrm{w}$ Internecie. Wynikać to może $\mathrm{z}$ braku świadomości, że ten kanał informacyjny może być bardzo ważny w życiu i aktywności społecznej szkół. Można to też interpretować jako brak kompetencji do wykonania takiej witryny lub braku środków na zlecenie jej wykonania. Najbardziej niekorzystną przyczyną nieobecności w sieci byłby brak „potrzeby istnienia w sieci”, wynikający z niewiedzy o możliwościach oferowanych przez sieć internetową oraz nieumiejętność wykorzystania narzędzi internetowych. W obecnych czasach tego typu postawa występuje marginalnie. Żartobliwe z pozoru stwierdzenie, że „jeśli nie ma cię w Internecie, to nie istniejesz", należałoby dziś traktować $\mathrm{z}$ większą powagą.

Przeglądając witryny podlaskich i mazowieckich szkół spotkamy się ze stronami, które rozsiewają wirusy, czyli zabezpieczenia takich witryn nie były wystarczające i strony zostały zarażone „złośliwym kodem”. W badanych szkołach znalazło się (ogółem) 3,1\% stron zarażonych „złośliwym kodem”. Zjawisko to nie występuje często, tym niemniej bardzo negatywnie wpływa na wizerunek placówki szkolnej: przy braku odpowiedniego oprogramowania antywirusowego osoby odwiedzające taką stronę mogą zostać zarażone złośliwymi wirusami. Porównując oba województwa można zauważyć, że witryny szkół w województwie podlaskim są częściej zawirusowanie $(5,1 \%)$ niż w województwie mazowieckim $(1,4 \%)$ - ale różnica stopnia „zhakowania” nie jest istotna statystycznie (czego przyczyną może być mała liczebność szkół w próbie i stosunkowo mały zakres zjawiska). Niepokojący jest jednak stan zabezpieczeń witryn szkolnych, gdzie 3,1\% z nich padło ofiarą włamań, co nie przesądza jednak o tym, że o pozostałych $96,9 \%$ witryn można powiedzieć, że są dobrze zabezpieczone przed włamaniem. Podstawowym błędem osób administrujących witrynami są: ustawianie słownikowych haseł (łatwe do odgadnięcia), używanie przestarzałych i niejednokrotnie dziurawych dodatków na stronach oraz brak świadomości i zainteresowania sprawami związanymi z bezpieczeństwem danych i metodami zabezpieczania się przed włamaniami, czyli stosowanie dobrych praktyk i nawyków, o których informacje są ogólnodostępne. 
Duży wpływ na widoczność witryny w internecie mają proste adresy. Przy obecnie dostępnych programach open source ${ }^{4}$, czyli takich, do których mamy dostęp nieodpłatnie oraz możliwościach, jakie one oferują uzyskanie tej funkcjonalności nie stanowi ani dużego trudu, ani rzeczy skomplikowanej w wykonaniu nawet dla laika. Witryny szkół w zdecydowanej większości używają CMS-ów ${ }^{5}$, czyli systemów zarządzania treścią witryny. W systemach tych w standardzie jest system prostych adresów, wystarczy tylko go użyć.

Przeanalizujmy, jak to wygląda w szkołach województwa mazowieckiego i podlaskiego. Proste adresy posiadało jedynie 19\% badanych szkół. Niekorzystnie wygląda sytuacja w województwie podlaskim (12,2\% szkół ma proste adresy) w porównaniu $\mathrm{z}$ mazowieckim $(34,7 \%)$. Niejednokrotnie brak tych adresów wynika tylko z braku ich ustawienia, co pokazuje tabela 1, w której widzimy, że funkcjonalność ta jest dostępna, ale nie jest używana przez wszystkich (w przypadku 24,3\% szkół nie udało się stwierdzić, czy witryna posiada CMS); 33,06\% witryn nie używa systemu zarządzania treścią, a w 66,94\% przypadków mamy możliwość ustawienia wyświetlania prostych adresów.

Tabela 1. Użycie systemu zarządzania treścią [\%]

\begin{tabular}{|c|c|c|}
\hline Systemy zarządzania treścią CMS & Ogółem & CMS \\
\hline Nie używa CMS & 25,0 & 33,06 \\
Wordpress & 3,8 & 4,96 \\
Joomla! & 20,6 & 27,27 \\
Inny CMS & 26,3 & 34,71 \\
\hline Brak danych & 24,3 & $\mathrm{X}$ \\
\hline Podstawa procentowania & 100,0 & 100,0 \\
\hline
\end{tabular}

Źródło: opracowanie własne.

Witryny szkół wyglądają różnorodnie, nie sposób spotkać dwóch identycznych. Jest jednak pewna ułomność występująca sporadycznie, ale wpływająca

\footnotetext{
4 Otwarte oprogramowanie (ang. open source movement, dosł. ruch otwartych źródeł) - odłam ruchu wolnego oprogramowania (ang. free software). http://pl.wikipedia.org/wiki/Otwarte_oprogramowanie [10.12.2012].

5 System zarządzania treścią (ang. Content Management System, CMS) jest to aplikacja internetowa lub ich zestaw, pozwalająca na łatwe utworzenie serwisu WWW oraz jego późniejszą aktualizację i rozbudowę przez redakcyjny personel nietechniczny. Kształtowanie treści i sposobu ich prezentacji w serwisie internetowym zarządzanym przez CMS odbywa się za pomocą prostych w obsłudze interfejsów użytkownika, zazwyczaj w postaci stron WWW zawierających rozbudowane formularze i moduły. źródło: http://pl.wikipedia.org/wiki/System_zarządzania_treścią [10.12.2012].
} 
negatywnie na postrzeganie takiej witryny. Mamy tu na myśli użycie pewnych technik do budowy strony, które powszechnie nie powinny w dzisiejszych czasach mieć już miejsca, użycie ramek (ang. frames), taka struktura budowy strony została wycofana ze specyfikacji HTML5, nie zaleca się też jej stosowania. Powodów jest kilka: strony tak zbudowane są znacznie mniej widoczne dla wyszukiwarek, adresy podstron są niewidoczne, co obniża pozycję naszej witryny, treści niemieszczące się w ramkach nie zostaną wyświetlone. 14,9\% przeanalizowanych stron używało w swojej budowie ramek. Różnice miedzy województwami okazały się nieistotne, 5,8\% w mazowieckim i $9,1 \% \mathrm{w}$ podlaskim stron ze wszystkich przeanalizowanych używało tej archaicznej budowy.

\section{Formy i narzędzia komunikacji oraz pozyskiwanie informacji i wiedzy}

Korzystanie z internetu przez jednostki szkół jako medium do komunikowania się niesie ze sobą bardzo wiele możliwości. Komunikacja może być jednostronna, co niejednokrotnie można zaobserwować w witrynach szkolnych, otrzymujemy informację, jednak nie zostaje wykorzystane żadne narzędzie z dużej puli możliwości, które mogłoby zebrać nasz respons. Dwustronna komunikacja istnieje w witrynach w bardzo znikomym stopniu. Przeanalizowaliśmy witryny mazowieckich i podlaskich szkół pod kątem istnienia forum do wymiany informacji i poglądów, użycia sond i ankiet, newsletterów ${ }^{6}$, formularzy kontaktowych oraz dodatków poszerzających sposoby komunikowania się jednostek szkół poprzez media społecznościowe oraz serwisy multimedialne.

Tabela 2. Narzędzia użyte do komunikacji [\%]

\begin{tabular}{|c|c|}
\hline Narzędzia komunikacyjne & Tak \\
\hline Formularz kontaktowy & 19,8 \\
Rejestracja w witrynie & 11,6 \\
Media społecznościowe (Facebook) & 10,7 \\
Użycie sondy/ankiety & 5,8 \\
Użycie newslettera & 5,8 \\
Forum & 5,0 \\
\hline
\end{tabular}

Źródło: opracowanie własne.

6 Newsletter - elektroniczna forma biuletynu - czasopisma rozsyłanego za pomocą poczty elektronicznej do prenumeratorów. Źródło: http://pl.wikipedia.org/wiki/Newsletter [10.12.2012]. 
Przeanalizowano również te zmienne $\mathrm{z}$ rozróżnieniem na województwa, $\mathrm{w}$ wynikach nie było istotnych różnic między mazowieckim i podlaskim. Województwa w bardzo niskim stopniu korzystają z możliwych form komunikacji dwustronnej, a nie wynika to z braku możliwości technicznych. Nie ogranicza nas w użyciu tych kanałów komunikacji system zarządzania treścią. Funkcjonalności wymienione $\mathrm{w}$ tabeli 1 są dostępne do zrealizowania poprzez standardowe dodatki do witryn, bądź przez dodatkowe, do których mamy dostęp nieodpłatnie. Narzędzia te są udostępniane na zasadzie open source. Wystarczy po nie sięgnąć i używać.

Przeglądając witryny szkół szukamy ciekawych odnośników na nich zamieszczonych, które mogą przekierować nas na inne strony, pełne wiedzy, dające możliwości zdobycia nowych umiejętności, poznania ciekawych zagadnień, nauczenia się i uzupełnienia posiadanej przez nas informacji. Spektrum odnośników może być bardzo szerokie od stron informacyjnych (szkoły wyższe, bazy danych, fora czy portale edukacyjne), do odnośników promujących ciekawe inicjatywy pobudzające lokalną społeczność. Różnice w występowaniu odnośników w witrynach województw mazowieckiego i podlaskiego okazały się statystycznie istotne. W województwie podlaskim witryny posiadające odnośniki występowały częściej (58,2\% podlaskich oraz 39,4\% mazowieckich witryn posiadało odnośniki).

E-learning stanowi technikę pozyskiwania informacji za pomocą zintegrowanych mediów elektronicznych dostępnych poprzez odpowiednio przygotowaną do tego celu platformę. Najpopularniejszym rozwiązaniem open source dostępnym na otwartej licencji jest Moodle ${ }^{7}$. Organizacja procesu dydaktycznego przy pomocy e-learningu charakteryzuje się dużym stopniem interaktywności. Wspomaga to złożony proces nauczania, umożliwia płynny przepływ informacji między uczestnikami. Daje także możliwość nauczania na odległość. Dostosowanie materiałów do potrzeb odbiorcy jest bardzo istotne, za pomocą mediów komputerowych dysponujemy wieloma rozwiązaniami, czy będzie to sam tekst, np. w formie pdf, grafika, audio czy też film. Za pomocą platformy e-learningowej mamy też możliwość weryfikowania pozyskanej wiedzy oraz kontaktu pomiędzy uczestnikami i prowadzącym. W jakim stopniu szkoła używa tego medium? Spośród wybranych losowo 160 szkół zaledwie 5,8\% witryn używa platformy e-learningowej. Różnice w wykorzystaniu platform edukacyjnych dla województwa mazowieckiego i podlaskiego okazały się statystycznie

\footnotetext{
Moodle (Modular Object-Oriented Dynamic Learning Environment) - środowisko nauczania zdalnego za pomocą sieci teleinformatycznych, dostępne przez przeglądarkę internetową. Platforma e-learningowa Moodle została stworzona na bazie Apache, PHP i MySQL lub PostgreSQL. Źródło: http:// pl.wikipedia.org/wiki/Moodle [10.12.2012].
} 
istotne: 10,9\% wybranych losowo szkół z województwa podlaskiego korzystało $\mathrm{z}$ tej formy nauczania, w porównaniu z mazowieckim, w którym ten wynik to tylko $1,5 \%$.

\section{Układ witryn, aktualności}

Treści prezentowane w witrynach można wzbogacać o dodatkowe zdjęcia, filmy, można też prezentować treści w bardziej rozbudowanej formie w postaci zbliżonej do dużych portali internetowych. Witryny szkół w większości były wyposażone $\mathrm{w}$ galerię zdjęć. $61,1 \%$ przeanalizowanych witryn posiadało galerię, na co w 6,6\% składała się galeria oferująca materiał nie w postaci statycznego obrazka, tylko jako film. Statystycznie istotnych różnic między województwami nie stwierdzono. Galeria stanowiła dość proste rozwiązanie ubarwiające oglądaną witrynę. Niektóre $\mathrm{z}$ wybranych witryn posiadały również dodatek ożywiający statyczny tekst na nich zamieszczany w postaci slidera, czyli sekwencji zdjęć płynnie przechodzących jedno w drugie za pomocą atrakcyjnej animacji. Witryn takich było zaledwie 9,9\%. Układ aktualności prezentowany na stronach w zdecydowanej większości, bo aż w 94,2\% nie odbiegał od prostego schematu, gdzie aktualności są prezentowane jedna pod drugą, bez żadnych dodatkowych modułów rozbudowujących formy prezentacji wybranych treści. Tylko 5,8\% witryn uatrakcyjniało prezentowane treści poprzez niestandardowy układ udostępniając dodatkowe moduły. Aktualności prezentowane na stronach okazywały się nieaktualne w 23,1\%, przy czym stwierdzono brak istotnych różnic między województwami.

\section{Wnioski i rekomendacje}

Analiza porównawcza szkół powszechnych (podstawowych, gimnazjalnych i ponadgimnazjalnych) województwa mazowieckiego (bez Warszawy) i województwa podlaskiego (bez Białegostoku) pokazuje interesujące zjawisko. Zjednej strony mamy potwierdzenie tradycyjnego obrazu strukturalnych zróżnicowań regionalnych: mniej szkół w województwie podlaskim (w porównaniu z mazowieckim) ma swoją witrynę szkolną w internecie i są to strony WWW mniej zaawansowane technologicznie w efekcie czego: bywają częściej „zawirusowane” w wyniku nieużywania aktualizowanych programów, komponen- 
tów składowych, w których luki w bezpieczeństwie zostały „załatane”, stanowiąc tym samym źródło infekcji dla potencjalnych użytkowników witryny; są gorzej zabezpieczone przed włamaniami (hakerami); nie używają dostępnych możliwości w systemach CMS; używają przestarzałych technologii („ramek”), które wychodzą z użycia i stanowią dla potencjalnych użytkowników „metakomunikat" o zacofaniu technologicznym witryny. Ten tradycyjny (strukturalny) obraz zróżnicowania regionalnego i zacofania województwa podlaskiego zderza się jednak ze znacznie odmiennym obrazem funkcjonalnego wykorzystania Internetu. To witryny szkół podlaskich posiadają większy zakres odnośników (linków) do innych witryn, a więc są silniej „usieciowione” - odsyłają swych użytkowników do innych źródeł informacji. Szkolna witryna WWW staje się w większym stopniu „oknem na świat”. Co więcej - witryny szkolne szkół podlaskich zdecydowanie częściej wykorzystują platformy e-learningowe niż szkoły województwa mazowieckiego. Jeśli „usieciowienie” (korzystanie z zasobów sieci internetowej) oraz używanie platform e-leraningowych (a więc technologii internetowej w procesie edukacyjnym) stanowią o tym, że szkoła przekracza "pogranicze” rzeczywistości realnej i wirtualnej, to szkoły województwa podlaskiego (mimo strukturalnego niedoinwestowania w technologie internetowe) wykazują przewagę funkcjonalną - dla szkół regionu internet rzeczywiście staje się medium pozwalających przekraczać bariery „wykluczenia cyfrowego” i partycypacji w przestrzeni kulturowej (wiedzy, informacji).

W związku z tym wydaje się, że władze oświatowe województwa podlaskiego powinny podjąć działania zorientowane na rozwój infrastruktury technicznej oraz zwiększenie efektywności funkcjonalnej stron WWW, w szczególności zmierzające w kierunku: (1) opracowania standardów funkcjonalności szkolnych witryn internetowych, standardów bezpieczeństwa i standardów związanych ze sposobem zarządzania informacją na witrynach szkolnych; (2) utworzenia listy darmowych („open source”) narzędzi wspomagających pracę osób publikujących treści lub zarządzających stronami szkolnymi, ułatwiających przygotowanie materiałów, które mogłyby się znaleźć w witrynie szkoły; (3) wsparcia szkół przez organizowanie szkoleń informatycznych w zakresie budowy i zarządzania informacją w witrynie szkolnej; (4) uruchomienia serwera dedykowanego dla szkól, który utrzymywałby standardy techniczne (szybkość, niezawodność, bezpieczeństwo danych zawartych w witrynach internetowych; (5) wyasygnowania środków finansowych przeznaczonych na utrzymanie w szkołach ,administratora” witryny. 


\section{Bibliografia}

Bard A. Soderqvist J. [2006] Netokracja: nowa elita władzy i życie po kapitalizmie, Warszawa Batorski D. [2009] Korzystanie z technologii informacyjno-komunikacyjnych, [w:] J. Czapiński, T. Panek (red.), Diagnoza Społeczna 2009. Warunki i jakość życia Polaków, Warszawa Bolter J.D. [1990] Człowiek Turinga: kultura Zachodu w wieku komputera, Warszawa Castells M. [2007] Społeczeństwo sieci, Warszawa Goban-Klas T. [2005] Cywilizacja medialna: geneza, ewolucja, eksplozja, Warszawa Jeran A. [2008] Wykluczenie cyfrowe - aspekty normatywne i rzeczywistość, [w:] A. Siwik, L.H. Haber (red.), Od robotnika do internauty. W kierunku społeczeństwa informacyjnego, Kraków

Jeran A. [2009] Kształcenie ustawiczne - demograficzna konieczność, „e-mentor”, nr 2

Krzysztofek K., Szczepański M.S. [2002] Zrozumieć rozwój: od społeczeństw tradycyjnych do informacyjnych, Katowice

Nowak A., Winkowska-Nowak K. [2009] Szkoła w dobie internetu, Warszawa 


\section{SUMMARY}

"School on the Internet": Podlaskie and Mazowieckie voivodeships - regional variations in the use of the Internet in primary, lower-secondary and secondary education

The article describes the regional variations in the use of the Internet in primary, lower-secondary and secondary schools in Podlaskie and Mazowieckie provinces. School sites were analyzed in terms of functionality, standards and the use of new forms and methods of creating the image of the website. The results showed different levels of the use of Internet technologies and the opportunities associated with them. What surprises is the minimal degree of utilization of two-way communication with the available tools and programs designed for this purpose.

\section{Keywords:}

The internet, regional differences, school websites 